\title{
Rapid response of arbuscular mycorrhizal fungal communities to short-term fertilization in an alpine grassland on the Qinghai-Tibet Plateau
}

Xingjia Xiang, Sean M Gibbons, Jin-Sheng He, Chao Wang, Dan He, Qian Li, Yingying Ni, Haiyan Chu

Background. The Qinghai-Tibet Plateau (QTP) is home to the vast grassland in China. The QTP grassland ecosystem has been seriously degraded by human land use practices and climate change. Fertilization is used in this region to increase vegetation yields for grazers. The impact of long-term fertilization on plant and microbial communities has been studied extensively. However, the influence of short-term fertilization on arbuscular mycorrhizal fungal (AMF) communities in the QTP is largely unknown, despite their important functional role in grassland ecosystems. Methods. We investigated AMF community responses to three years of $\mathrm{N}$ and/or $\mathrm{P}$ addition at an experimental field site on the QTP, using the Illumina MiSeq platform (PE 300). Results. Fertilization resulted in a dramatic shift in AMF community composition and NP addition significantly increased AMF species richness and phylogenetic diversity. Aboveground biomass, available phosphorus, and $\mathrm{NO}_{3}{ }^{-}$were significantly correlated with changes in AMF community structure. Changes in these factors were driven by fertilization treatments. Thus, fertilization had a large impact on AMF communities, mediated by changes in aboveground productivity and soil chemistry. Discussion. Prior work has shown how plants often lower their reliance on AMF symbioses following fertilization, leading to decrease AMF abundance and diversity. However, our study reports a rise in AMF diversity with fertilization treatment. Because AMF can provide stress tolerance to their hosts, we suggest that extreme weather on the QTP may help drive a positive relationship between fertilizer amendment and AMF diversity. 
1

2 Title: Rapid response of arbuscular mycorrhizal fungal communities to short-term fertilization in

3 an alpine grassland on the Qinghai-Tibet Plateau

4 Authors: Xingjia Xiang ${ }^{1,5}$, Sean M. Gibbons², Jin-Sheng He ${ }^{3,4}$, Chao Wang ${ }^{3}$, Dan $\mathrm{He}^{1}$, Qian $\mathrm{Li}^{4}$, 5 Yingying $\mathrm{Ni}^{1}$, Haiyan $\mathrm{Chu}^{1, *}$

6

$7{ }^{1}$ State Key Laboratory of Soil and Sustainable Agriculture, Institute of Soil Science, Chinese 8 Academy of Sciences, East Beijing Road 71, Nanjing 210008, China

$9{ }^{2}$ Department of Biological Engineering, Massachusetts Institute of Technology, Cambridge, MA 10 02139, USA

${ }^{3}$ Department of Ecology, College of Urban and Environmental Sciences, and Key Laboratory for Earth Surface Processes of the Ministry of Education, Peking University, Beijing 100871, China. ${ }^{4}$ Key Laboratory of Adaptation and Evolution of Plateau Biota, Northwest Institute of Plateau Biology, Chinese Academy of Sciences, Xining 810008, China.

${ }^{5}$ University of Chinese Academy of Sciences, Beijing 100049, China

\section{*Corresponding author: Haiyan Chu}

Corresponding address: State Key Laboratory of Soil and Sustainable Agriculture, Institute of Soil Science, Chinese Academy of Sciences, East Beijing Road 71, Nanjing 210008, China. Email: hychu@issas.ac.cn 
21

\section{Abstract}

Background. The Qinghai-Tibet Plateau (QTP) is home to the vast grassland in China. The QTP grassland ecosystem has been seriously degraded by human land use practices and climate change. Fertilization is used in this region to increase vegetation yields for grazers. The impact of long-term fertilization on plant and microbial communities has been studied extensively. However, the influence of short-term fertilization on arbuscular mycorrhizal fungal (AMF) communities in the QTP is largely unknown, despite their important functional role in grassland ecosystems.

Methods. We investigated AMF community responses to three years of $\mathrm{N}$ and/or P addition at an experimental field site on the QTP, using the Illumina MiSeq platform (PE 300).

Results. Fertilization resulted in a dramatic shift in AMF community composition and NP addition significantly increased AMF species richness and phylogenetic diversity. Aboveground biomass, available phosphorus, and $\mathrm{NO}_{3}{ }^{-}$were significantly correlated with changes in AMF community structure. Changes in these factors were driven by fertilization treatments. Thus, fertilization had a large impact on AMF communities, mediated by changes in aboveground productivity and soil chemistry.

Discussion. Prior work has shown how plants often lower their reliance on AMF symbioses following fertilization, leading to decrease AMF abundance and diversity. However, our study reports a rise in AMF diversity with fertilization treatment. Because AMF can provide stress tolerance to their hosts, we suggest that extreme weather on the QTP may help drive a positive relationship between fertilizer amendment and AMF diversity.

Keywords: Plateau, Fertilization, Arbuscular mycorrhizal fungi, Community, Diversity 


\section{Introduction}

The Qinghai-Tibetan Plateau (QTP), also known as the 'Roof of the World' or the 'Third Pole', is famous for its extreme weather and plays a crucial role in providing ecological stability and climate buffering to the region (Dong et al., 2010). About 85\% of the QTP is grassland, accounting for more than $30 \%$ of all grassland area in China. However, this ecosystem is being degraded by long-term livestock overgrazing and climate change, which have created a series of social, environmental, and economic crises (Wen et al., 2013). Chemical fertilizers (i.e. N, P) are widely used in this region to increase vegetation yields for grazing (Beauchamp, Trevors \& Paul, 1989; Hacker, Toole \& Melville, 2011; Zhou et al., 2015). $\mathrm{N}$ is usually considered the major limiting element for plant and microbial growth in most terrestrial ecosystems (Elser et al., 2007; Lebauer \& Treseder, 2008). Recently, it has been argued that phosphorous is equally important in many terrestrial ecosystems (Vitousek et al., 2010; Harpole et al., 2011). Nitrogen addition has a marked effect on soil phosphorus availability, as $\mathrm{N}$ addition induces a shift in soil nutrient limitation from $\mathrm{N}$ to $\mathrm{P}$ and vice versa (Lü et al., 2013).

Fertilization greatly alters soil $\mathrm{N}$ and $\mathrm{P}$ cycling, which has a profound impact on structure and function of grassland ecosystems. Empirical studies have shown how fertilization significantly reduces plant root biomass (Bloom, Chapin \& Mooney, 1985) and grass species diversity (Bai et al., 2010; Clark and Tilman, 2008). Forb biomass generally increases with fertilizer amendment (Heil and Bruggink, 1987; Herron et al., 2001; Zhang et al., 2011). Fertilization is known to alter successional trajectories (Tilman, 1987) and promote the establishment of invasive plant species (Huenneke et al., 1990). Nitrogen and phosphorus addition have significantly altered soil organic carbon in arctic tundra (Mack et al., 2004) and soil carbon fractions in an alpine meadow ( $\mathrm{Li}$ et al., 2014). Long-term fertilization has been associated with significant decreases of soil microbial biomass and bacterial diversity, and is known to drive shifts in bacterial community composition in grassland ecosystems (Lovell, Jarvis \& Bardgett, 1995; Ramirez et al., 2010; Allison et al., 2013) and agriculture soils (Enwall et al., 2007; Yuan et al., 2012; Sun et al., 2015). Soil fungal communities are also altered by 
70

71

72

73

74

75

76

77

78

79

80

81

82

83

84

fertilization in forest (Liu et al., 2012a), agricultural (Avio et al., 2013), and grassland ecosystems (Klabi et al., 2015). Arbuscular mycorrhizal fungal (AMF) communities were significantly altered by long-term balanced fertilization in agriculture (Lin et al., 2012) and grassland soils (Liu et al., 2012b). Despite a substantial body of work on how long-term fertilization affects soil biogeochemistry and microbial community structure, the response of AMF communities to short-term fertilization (e.g. three years in this study) is not well understood.

AMF form mutualistic symbioses with $>80 \%$ of land plants, providing their hosts with nutrients and stress tolerance in exchange for photosynthate (van der Heijden et al., 1998a; Moora et al., 2004; Smith \& Read, 2008). AMF communities are structured largely by plant communities (Johnson et al., 2004; Börstler et al., 2006; Hausmann \& Hawkes, 2009), as most AMF taxa show some level of host-preferences (Fitter, 2005; Öpik et al., 2009). The correlation between plant diversity and AMF richness has been reported as positive (Landis, Gargas \& Givnish, 2004; Wu et al., 2007), non-significant (Börstler et al., 2006; Öpik et al., 2008) or negative (Antoninka, Reich \& Johnson, 2011). AMF-plant mutualisms depend on soil nutrient availability and weather conditions. Under high-nutrient conditions, plants obtain enough nutrients without their AMF partners (Lin et al., 2012), which can lead to a reduction in carbon allocated to the roots (Brouwer, 1983) and an overall drop in AMF abundance (Johnson, 2010). Some researchers have argued that the relationship between plants and AMF may even shift from mutualism to parasitism in a nutrient-rich environment (Johnson, 1993; Chu et al., 2016). In addition to nutrient acquisition, AMF can help buffer their plant hosts from environmental stress (e.g. cold and drought) by causing shifts in host physiology (Miransari et al., 2008). AMF colonization has been shown to increase under stressful conditions, which is thought to improve plant performance by inducing increased production of secondary metabolites, higher enzymatic activities, and greater plasma membrane permeability. (Bunn et al., 2009; Chen et al., 2013). We designed the following study to investigate the response of AMF communities to short-term fertilization in an alpine grassland on the QTP. In particular, we addressed two main questions: (i) 
97 how does short-term fertilization affect AMF community structure on QTP; and (ii) what

98 99

100

101

102

103

104

105

106

107

108

109

110

111

112

113

114

115

116

117

118

119

120

121

122

123

environmental parameters shape AMF community structure following fertilization?

\section{Materials and Methods}

\section{Site selection and soil sampling}

The fertilization addition experiment started in 2011 (37³7’ $\left.\mathrm{N}, 101^{\circ} 12^{\prime} \mathrm{E} ; 3220 \mathrm{~m}\right)$, at the Haibei Alpine Grassland Ecosystem Experimental Station (QTP station), which was established in 1976 (northeast of QTP; 37²9'-3745'N, 101 $12^{\prime}-101^{\circ} 23^{\prime} \mathrm{E}$ ). The Haibei Alpine Grassland Ecosystem Experimental Station provided us with the necessary permits to carry out this work. The field sites were strictly vetted based on our selection standards: Mat-Cryic Cambisols soil type, vegetation type, and environmental conditions. The area has a typical plateau/continental climate, with a long winter. The average annual temperature is $-1.7^{\circ} \mathrm{C}$, with a maximum temperature of $27.6{ }^{\circ} \mathrm{C}$ and a minimum temperature of $-37.1{ }^{\circ} \mathrm{C}$.

Soils were collected on the $12^{\text {th }}$ of August, 2014, at QTP Station. The experimental plots were constructed in randomized block design and the plot was a $6 \times 6 \mathrm{~m}$ square. Our study included four treatments, with five replicates each: Control (without fertilization); N (100 kg N $\left.\mathrm{ha}^{-1} \mathrm{yr}^{-1}\right)$; P (50 kg P ha-1 $\left.\mathrm{yr}^{-1}\right)$; and NP (100 kg N ha-1 $\mathrm{yr}^{-1}$ and $50 \mathrm{~kg} \mathrm{P} \mathrm{ha}^{-1} \mathrm{yr}^{-1}$ ) (Table S1). Our fertilizer amendment amounts fall within an intermediate range of what other studies report (Sun et al. 2015; Zeng et al., 2015). The fertilizers were urea and $\mathrm{Ca}\left(\mathrm{H}_{2} \mathrm{PO}_{4}\right)_{2}$, applied on the first days of June, July and August (i.e. during the main growing season). In each plot, soils were collected from 4 corners of the plot ( $1 \mathrm{~m}$ from edge of plot to avoid edge effects and at a depth of $0-10 \mathrm{~cm}$ ) and then mixed together into one sample. The soils were kept in a cooler and shipped refrigerated to the lab as quickly as possible. The samples were completely mixed within each bag and sieved to remove stones, and then divided into three parts: one part was for biogeochemical analysis and was stored at $4{ }^{\circ} \mathrm{C}$; the second part was stored at $-20{ }^{\circ} \mathrm{C}$ for DNA extraction and the third part was placed in long-term storage at $-40{ }^{\circ} \mathrm{C}$. 
124

125

126

127

128

129

130

131

132

133

134

135

136

137

138

139

140

141

142

143

144

145

146

147

148

149

150

\section{Vegetation and soil properties analyses}

Aboveground Net Primary Productivity (ANPP) were assessed in four $0.5 \times 0.5 \mathrm{~m}$ areas, at the corners of soil plots. Aboveground portion of biomass was collected from a plot using clipper. Plants were grouped visually into four categories: Gramineae, Sedge, Legume and Forb. In each plot, the roots from three replicate soil cores which were collected using a $7 \mathrm{~cm}$ diameter auger were used to estimate belowground root biomass. The dry biomass for aboveground sections and belowground roots (after washing) were calculated after $48 \mathrm{~h}$ in the $65^{\circ} \mathrm{C}$ oven. Soil $\mathrm{pH}$ was measured after shaking a soil water suspension (1:5 wt/vol) for $30 \mathrm{~min}$ and soil moisture (SM) was measured gravimetrically. The classical methods were applied for measuring soil available phosphorus (AP, Stahlberg, 1980), total phosphorus (TP, Bowman, 1988), total carbon (TC) and total nitrogen (TN) (Walkley \& Black, 1934). Soil dissolved organic C (DOC) and total dissolved $\mathrm{N}$ (TDN) and mineral nitrogen were extracted by adding $50 \mathrm{ml}$ of $0.5 \mathrm{M} \mathrm{K}_{2} \mathrm{SO}_{4}$ to $10 \mathrm{~g}$ fresh soil, shaking for $1 \mathrm{~h}$ and then vacuum filtering through glass fiber filters (Fisher G4, $1.2 \mu \mathrm{m}$ pore space). Ammonium $\left(\mathrm{NH}_{4}^{+}\right)$and nitrate $\left(\mathrm{NO}_{3}^{-}\right)$contents in the extracts were determined colorimetrically by automated segmented flow analysis (Bran + Luebbe AAIII, Germany) using the salicylate/dichloroiso- cyanuric acid and cadmium column/sulphanilamide reduction methods, respectively. DOC and TDN were determined using a TOC-TN analyzer (Shimadzu, Kyoto, Japan). Dissolved organic N (DON) was calculated as follows: DON $=$ TDN $-\mathrm{NH}_{4}{ }^{+}-\mathrm{NO}_{3}{ }^{-}$. Biogeochemical data are shown in Table S2.

\section{Soil DNA extraction}

DNA extractions were carried out on $0.5 \mathrm{~g}$ soil according to the manufacturer's instructions (FastDNA $^{\circledR}$ SPIN Kit for soil, MP Biomedicals, Santa Ana, CA). The extracted DNA was dissolved in $50 \mu \mathrm{l}$ TE buffer, quantified by NanoDrop ND-1000 (Thermo Scientific, USA) and stored at $-20^{\circ} \mathrm{C}$.

\section{PCR and amplicon library preparation}


151 Primers AMV4.5NF and AMDGR (Lumini et al., 2010) were used to amplify soil 18S rRNA 152 gene fragments for the Illumina MiSeq platform (PE 300) at Novogene (Beijing, China). PCR 153 was carried out in 50- $\mu 1$ reaction mixtures containing each deoxynucleoside triphosphate at a 154 concentration of $1.25 \mathrm{mM}, 1 \mu \mathrm{l}$ of forward and reverse primers $(20 \mu \mathrm{M}), 2 \mathrm{U}$ of Taq DNA 155 polymerase (TaKaRa, Japan), and $50 \mathrm{ng}$ of DNA. The following cycling parameters were used: 15635 cycles $\left(95{ }^{\circ} \mathrm{C}\right.$ for $45 \mathrm{~s}, 56{ }^{\circ} \mathrm{C}$ for $45 \mathrm{~s}$, and $72{ }^{\circ} \mathrm{C}$ for $45 \mathrm{~s}$ ) were performed with a final 157 extension at $72{ }^{\circ} \mathrm{C}$ for $10 \mathrm{~min}$. Triplicate reaction mixtures per sample were pooled together and 158 purified using an agarose gel DNA purification kit (TaKaRa), and quantified using NanoDrop ND-1000 (Thermo Scientific, USA) ranging from 44.2 to $82.7 \mathrm{ng} / \mu \mathrm{l}$. The bar-coded PCR products were pooled in equimolar amounts (10 pg for each sample) before sequencing.

\section{Processing of sequence data}

Sequences were merged by FLASH (Magoc \& Salzberg, 2011) and then processed using Quantitative Insights Into Microbial Ecology (QIIME; http://www.qiime.org/) (Caporaso et al., 2010). Poor-quality sequences (below an average quality score of 25) and short sequences $(<200$ bp) were removed. Sequences were clustered into Operational Taxonomic Units (OTUs) using a 97\% identity threshold (default QIIME settings) by UCLUST (Edgar, 2010) and all singleton OTUs were deleted. Chimera filtering was also performed to remove sequencing errors with USEARCH tool (version 1.8.0) in QIIME. The most abundant sequence within each cluster was selected as the representative sequence for that OTU. The representative sequences were checked against the MaarjAM AMF database (Öpik et al., 2010; http://maarjam.botany.ut.ee/). We rarified the abundance matrix to 1,000 sequences per sample to obtain normalized relative 173 abundances.

\section{Statistical analysis}

Phylogenetic diversities (PD) were estimated by Faith's index (Faith, 1992), providing an

177 integrated index of the phylogenetic breadth across taxonomic levels. Pearson correlations were 
178

179

180

181

182

183

184

185

186

187

188

189

190

191

192

193

194

195

196

197

198

199

200

201

202

203

calculated between AMF alpha-diversity and biogeochemical properties using SPSS 20 for Windows. A neighbor-joining tree (MEGA 6; Tamura et al., 2013) was built for phylogenetic assignment by aligning dominant AMF OTU sequences (relative abundance $>1 \%$ ) with known reference sequences. The response ratio (RR) was used to quantify significant responses of OTUs to fertilization. Only those OTUs detected in more than 3 replicates of each treatment were analyzed. The $95 \%$ confidence interval $(\mathrm{CI})=r r_{i} \pm 1.96 \times \sqrt{\mathrm{V}_{i}}$, where $r r_{i}=\ln \left(\overline{\mathrm{X}_{i}} / \overline{\mathrm{y}_{i}}\right)(i=$ $1 \cdots n), \overline{\mathrm{x}}$ is the mean OTU read number in fertilization samples and $\overline{\mathrm{y}}$ is the mean OTU read number in control samples; the variance $\left(V_{i}\right)$ is, $V_{i}=\frac{\mathrm{s}_{x_{i}}{ }^{2}}{\mathrm{~m}_{\mathrm{x}_{\mathrm{i}}} \overline{\mathrm{x}}_{\mathrm{i}}^{2}}+\frac{\mathrm{s}_{\mathrm{y}_{\mathrm{i}}}{ }^{2}}{\mathrm{~m}_{\mathrm{y}_{\mathrm{i}}} \overline{\mathrm{y}}_{\mathrm{i}}{ }^{2}}(\mathrm{i}=1 \cdots \mathrm{n})$, where $s$ is the SD of OTU $i$ in control and fertilization samples and $m$ is the abundance of OTU $i$ in control and fertilization samples. The rr-significance value was calculated using the equation: $r r$ significance $=\left(r r_{i}+1.96 \sqrt{V_{i}}\right) \times\left(r r_{i}-1.96 \sqrt{V_{i}}\right)$. If the $95 \%$ CI of a response variable overlaps with zero (rr-significance $<0$ ), the response ratio at fertilization is not significantly different from the control. If rr-significance $>0$, the response ratio is significant (Luo, Hui and Zhang, 2006; Xiang et al., 2015). Non-metric multidimensional scaling (NMDS) based on Bray-Curtis dissimilarity (calculated from the relative abundance matrix), and Analyses of Similarities (ANOSIM) (Clarke, 1993) were performed to compare community composition in different treatments in the vegan package 2.0-10 (Dixon, 2003) of R v.3.1.0 (R Development Core Team. Vienna, Austria). Mantel tests were used to identify biogeochemical factors that significantly correlated with community composition. Multivariate regression trees (MRT) were constructed to display important relationships between AMF community and biogeochemical variables in the mvpart package 1.2-6 (De'ath, 2002).

\section{Results}

\section{General sequencing information}

We obtained a total of 380,203 quality-filtered fungal sequences across all soil samples for the primer pair AMV4.5NF/AMDGR: 12.14\% were classified as Glomeromycota (AMF). A total of 
204

205

206

207

208

209

210

211

212

213

214

215

216

217

218

219

220

221

222

223

224

225

226

227

228

229

230

46,140 quality-filtered AMF sequences were identified across all the entire data set, ranging from 1,088-4,313 sequence reads per sample (mean =2,307). The neighbor-joining tree showed that the dominant OTUs (relative abundance > 1\%) grouped into Claroideoglomeraceae (30.1\%), Gigasporaceae (23.9\%), Glomeraceae (23.4\%), Diversisporaceae (12.6\%) and Acaulosporaceae (9.1\%) families (Fig. S1-2). In addition, Ambisporaceae, Archaeosporaceae, Pacisporaceae were present in most soils but at relatively low abundances, indicating a good coverage of the Glomeromycota.

\section{Arbuscular mycorrhizal fungal alpha-diversity}

After rarefaction to an equal sequencing depth per sample $(1,000)$, we found a total of 231 distinct AMF OTUs across all samples (97\% similarity), 35.5\% of which (82) were found in all treatments. There were 132, 131, 143 and 169 AMF OTUs in Control, N, P and NP treatments, respectively. In addition, there were unique OTUs within each treatment, especially for NP plots, where the unique OTUs accounted for $19.5 \%$ of the 169 distinct OTUs observed (Fig. 1). Soil AMF alpha-diversity (i.e. OTU richness and phylogenetic diversity) was calculated at a depth of 1,000 randomly selected sequences per sample. Compared to control soils, NP addition significantly increased AMF OTU richness and phylogenetic diversity in this study (Fig. 2). Of all the biogeochemical characteristics examined, both OTU richness and phylogenetic diversity were positively correlated with $\mathrm{NO}_{3}{ }^{-}, \mathrm{DON}$, AP, graminoid biomass, forb biomass and $\mathrm{TB}$ and negatively correlated with legume biomass $(P<0.05$ in all cases; Table S3).

\section{Arbuscular mycorrhizal fungal community composition}

Compared to control plots, NP addition significantly decreased the relative abundance of Gigasporaceae and increased the relative abundance of Glomeraceae. The relative abundance of Diversisporaceae showed significant increase and the relative abundance of Acaulosporaceae showed significant decrease in N, P and NP plots relative to control soils (Fig. 3). Response ratios were calculated in order to identify significant differences across control and fertilization 
231

232

233

234

235

236

237

238

239

240

241

242

243

244

245

246

247

248

249

250

251

252

253

254

255

256

257

samples (Fig. 4). In the family Diversisporaceae, all OTUs showed significant increases in abundance, and for Acaulosporaceae, all the OTUs showed significant decreases in abundance in fertilization plots. In the family Gigasporaceae, all OTUs in P and NP plots showed negative responses relative to the control, and for the family Glomeraceae, all OTUs showed positive responses in NP plots relative to the control.

AMF community composition was significantly influenced by short-term fertilization (Fig. 5; Table S4). Mantel tests showed that the AMF community composition was significantly correlated with $\mathrm{AP}, \mathrm{NO}_{3}{ }^{-}$, TP, graminoid biomass, legume biomass, forb biomass and total aboveground biomass (TB) $(P<0.05$ in all cases, Table S5). In addition, MRT analysis was used to investigate the effects of biogeochemical variables on AMF communities. The MRT model explained $37.0 \%$ of detected variation in AMF community composition. The important factors were AP, TB and legume biomass, which accounted for $20.5 \%, 8.4 \%$ and $7.1 \%$ variation of AMF community composition, respectively (Table S6). Both AP and TB showed significant Pearson correlations with the relative abundance of Claroideoglomeraceae, Gigasporaceae and Acaulosporaceae; Both soil DON and forb biomass showed significant Pearson correlations with the relative abundance of Glomeraceae and Acaulosporaceae; TP showed significant Pearson correlations with the relative abundance of Gigasporaceae and legume biomass showed significant Pearson correlations with the relative abundance of Glomeraceae $(P<0.05$ in all cases; Table S7).

\section{Discussion}

Chemical fertilizers (i.e. N, P) are common remediation tools that help maximize biomass production and prevent desertification in grassland ecosystems (Beauchamp, Trevors \& Paul, 1989; Hacker, Toole \& Melville, 2011). Despite a substantial body of work on how long-term fertilization affects vegetation and belowground microbial communities, effects of short-term fertilization on soil microbes in alpine grasslands remains largely unexamined. Our study was performed at a well-managed field station, where site conditions were well documented prior to 
258 our fertilization study. We examine the effects of short-term fertilization on soil AMF 259 communities, as AMF are ubiquitous and play a major role in grassland ecosystem function (van 260 der Heijden et al., 1998b; Johnson et al., 2004; Gianinazzi et al., 2010). The most dominant 261 AMF family in this ecosystem was Claroideoglomeraceae. Glomeraceae is usually predominant 262 in agriculture (Oehl et al., 2005; Hijri et al., 2006; Lin et al., 2012), grassland (Maherali \& 263 Klironomos, 2012; Zangaro et al., 2013) and forest ecosystems (Helgason et al., 2007; Xiang et 264 al., 2015; Chu et al., 2016) around the world, which highlights the unique nature of the QTP. 265 Short-term fertilization significantly altered soil properties (i.e. AP, TP, $\mathrm{NO}_{3}^{-}$and DON) and 266 aboveground biomass, suggesting rapid response of biogeochemical properties to fertilization. 267 We found that short-term fertilization resulted in a dramatic shift of AMF communities, which 268 was corroborated by results from other studies in grassland (Porras-Alfaro et al., 2007; Liu et al., 269 2012b; Chen et al., 2014) and agriculture soils (Antoninka, Reich \& Johnson, 2011; Lin et al., 270 levels. AMF communities showed strong correlations with $\mathrm{AP}, \mathrm{NO}_{3}{ }^{-}$and aboveground biomass, suggesting that the effects of fertilization on AMF communities are mediated by changes in vegetation structure and soil chemistry.

Generally, fertilized plants can obtain enough nutrients from soil without their AMF partners, which lowers the reliance of the plant community on AMF symbioses (Johnson, 1993). Higher soil nutrient levels have been shown to decrease root biomass (Bloom, Chapin \& Mooney, 1985) and increase aboveground biomass (i.e. light; Hautier, Niklaus \& Hector, 2009). Thus, fertilized plants reduce their allocation of belowground carbon (Brouwer, 1983) and thereby reduce the abundance and diversity of AMF mutualists (Johnson, 2010). Conversely, in our study NP fertilization led to a slight increase in root biomass and a marked increased AMF alpha-diversity. Despite reduced reliance on AMF mutualists for nutrients in the presence of fertilizers, plants may still rely on AMF-mediated stress tolerance to deal with the extreme weather conditions (e.g. cold) common to the QTP (Chen et al., 2013). Fertilizer-induced changes in the AMF communities could reflect selection for mutualisms that promote stress 
285

286

287

288

289

290

291

292

293

294

295

296

297

298

299

300

301

302

303

304

305

306

307

308

309

310

311

tolerance. For example, previous studies have shown that certain AMF, primarily within the family of Glomeraceae, provide their hosts with improved cold tolerance (Zhu, Song \& Xu, 2010; Chen et al., 2013). We found that the relative abundance of Glomeraceae significantly increased in response to NP treatment.

NP fertilization led to a two-fold increase in grass biomass, with a slight increase in root biomass. Thus, the absolute amount of photosynthate available to AMF may have remained constant, or even increased. We propose the following model for fertilization in the QTP: NP fertilization increases grass biomass; higher overall photosynthesis allows for a sufficient carbon flux to the root system to support AMF mutualists; AMF provide their host with improved stress tolerance. As belowground carbon allocation increases, competition between AMF is reduced and rare species are better able to persist. In addition, several studies have demonstrated that fertilization increases the occurrence of non-native plant species (Huenneke et al., 1990; Hobbs et al., 1998; Ostertag \& Verville, 2002). AMF taxa show a certain degree of host preference (Vandenkoornhuyse et al., 2003; Fitter, 2005; Öpik et al., 2009; Liu et al., 2011b), which might in turn increase AMF diversity in the presence of non-native plants (Lekberg et al., 2013).

\section{Conclusions}

In conclusion, our study shows that fertilization increases AMF community diversity in the QTP, which is the opposite of what has been found in several other studies. We suggest that both soil nutrients and stress tolerance should be considered in order to thoroughly evaluate the effect of fertilization on AMF communities on QTP. This work helps to build a more complete picture of how AMF communities respond to fertilization across different ecosystems. Future work should focus on more detailed plant data and longitudinal sampling (short, intermediate and long-term) following fertilization to identify the feedbacks between plant and AMF communities over time.

\section{Acknowledgements}

We thank Ms. Kaoping Zhang and Dr. Ruibo Sun from Institute of Soil Science, Chinese 
312 Academy of Sciences, for assistance in soil sampling. We also thank Dr. Yu Shi from Institute of 313 Soil Science, Chinese Academy of Sciences, for useful discussion.

315 Additional Information and Declarations

316 Sequence Deposition

317 Sequences (raw data) were submitted to the Sequence Read Archive (SRA) of NCBI under the 318 accession number SRP072405. 
319

320

321

322

323

324

325

326

327

328

329

330

331

332

333

334

335

336

337

338

339

340

341

342

343

\section{References}

Allison SD, Lu Y, Weihe C, Goulden ML, Martiny AC, Treseder KK, Martiny JBH. 2013. Microbial abundance and composition influence litter decomposition response to environmental change. Ecology 94:714-725 DOI 10.1890/12-1243.1.

Antoninka A, Reich PB, Johnson NC. 2011. Seven years of carbon dioxide enrichment, nitrogen fertilization and plant diversity influence arbuscular mycorrhizal fungi in a grassland ecosystem. New Phytologist 192:200-214 DOI 10.1111/j.14698137.2011.03776.x.

Avio L, Castaldini M, Fabiani A, Bedini S, Sbrana C, Turrini A, Giovannetti M. 2013. Impact of nitrogen fertilization and soil tillage on arbuscular mycorrhizal fungal communities in a Mediterranean agroecosystem. Soil Biology and Biochemistry 67:285294 DOI 10.1016/j.soilbio.2013.09.005.

Bai YF, Wu JG, Clark CM, Naeem S, Pan QM, Huang JH, Zhang LX, Han XG. 2010. Tradeoffs and thresholds in the effects of nitrogen addition on biodiversity and ecosystem functioning: evidence from inner Mongolia Grasslands. Global Change Biology 16:358372 DOI 10.1111/j.1365-2486.2009.01950.x.Beauchamp EG, Trevors JT, Paul JW. 1989. Carbon sources for bacterial denitrification. Advances in Soil Science 10:113-142 DOI 10.1007/978-1-4613-8847-0_3.

Bloom AJ, Chapin FS, Mooney HA. 1985. Resource limitation in plants: an economic analogy. Annual Review of Ecology and Systematics 16:363-393 DOI 10.1146/annurev.es.16.110185.002051.

Börstler B, Renker C, Kahmen A, Buscot F. 2006. Species composition of arbuscular mycorrhizal fungi in two mountain meadows with differing management types and levels of plant biodiversity. Biology and Fertility of Soils 42:286-298 DOI 10.1007/s00374-0050026-9. 
344

345

346

347

348

349

350

351

352

353

354

355

356

357

358

359

360

361

362

363

364

365

366

367

Bowman RA. 1988. A rapid method to determine total phosphorus is soils. Soil Science Society of America Journal 52:1301-1304 DOI 10.2136/sssaj1988.03615995005200050016x.

Brouwer R. 1983. Functional equilibrium: sense or nonsense? Netherlands journal of agricultural science 31:335-348.

Bunn R, Lekberg Y, Zabinski C. 2009. Arbuscular mycorrhizal fungi ameliorate temperature stress in thermophilic plants. Ecology 90:1378-1388 DOI: 10.1890/07-2080.1.

Caporaso JG, Kuczynski J, Stombaugh J, Bittinger K, Bushman FD, Costello EK, Fierer N, Peña AG, Goodrich JK, Gordon JI, Huttley GA, Kelley ST, Knights D, Koenig JE, Ley RE, Lozupone CA, McDonald D, Muegge BD, Pirrung M, Reeder J, Sevinsky JR, Turnbaugh PJ, Waters WA, Widmann J, Yatsuneko T, Zaneveld J, Knight R. 2010. QIIME allows analysis of high-throughput community sequencing data. Nature Methods 7:335-336 DOI 10.1038/nmeth.f.303.

Chen SC, Jin WJ, Liu AR, Zhang SJ, Liu DL, Wang FH, Lin XM, He CX. 2013. Arbuscular mycorrhizal fungi (AMF) increase growth and secondary metabolism in cucumber subjected to low temperature stress. Scientia Horticulturae 160:222-229 DOI 10.1016/j.scienta.2013.05.039.

Chen Y, Zhang X, Ye J, Han H, Wan S, Chen B. 2014. Six-year fertilization modifies the biodiversity of arbuscular mycorrhizal fungi in a temperate steppe in Inner Mongolia. Soil Biology and Biochemistry 69:371-381 DOI 10.1016/j.soilbio.2013.11.020.

Chu H, Xiang X, Yang J, Adams J, Zhang K, Li Y, Shi Y. 2016. Effects of slope aspects on soil bacterial and arbuscular fungal communities in a boreal forest in China. Pedosphere 26:226-234 DOI 10.1016/S1002-0160(15)60037-6.

Clark CM, Tilman D. 2008. Loss of plant species after chronic low-level nitrogen deposition to prairie grasslands. Nature 451:712-715 DOI 10.1038/nature06503. 
Clarke KR. 1993. Non-parametric multivariate analyses of changes in community structure. Australian Journal of Ecology 18:117-143 DOI 10.1111/j.1442-9993.1993.tb00438.x.

De'ath G. 2002. Multivariate regression trees: a new technique for modeling speciesenvironment relationships. Ecology 83:1105-1117 DOI 10.1890/00129658(2002)083[1105:MRTANT]2.0.CO;2.

Dixon P. 2003. VEGAN, a package of R functions for community ecology. Journal of Vegetation Science 14:927-930 DOI 10.1111/j.1654-1103.2003.tb02228.x.

Dong SK, Wen L, Zhu L, Li XY. 2010. Implication of coupled natural and human systems in sustainable rangeland ecosystem management in HKH region. Frontiers of Earth Science in China 4:42-50 DOI 10.1007/s11707-010-0010-z.

Edgar RC. 2010. Search and clustering orders of magnitude faster that BLAST. Bioinformatics 26:2460-2461 DOI 10.1093/bioinformatics/btq461.

Elser JJ, Bracken MES, Cleland EE, Gruner DS, Harpole WS, Hillebrand H, Ngai JT, Seabloom EW, Shurin JB, Smith JE. 2007. Global analysis of nitrogen and phosphorus limitation of primary producers in freshwater, marine and terrestrial ecosystems. Ecology Letters 10:1135-1142 DOI 10.1111/j.1461-0248.2007.01113.x.

Enwall K, Nyberg K, Bertilsson S, Cederlund H, Stenström J, Hallin S. 2007. Long-term impact of fertilization on activity and composition of bacterial communities and metabolic guilds in agricultural soil. Soil Biology and Biochemistry 39:106-115 DOI 10.1016/j.soilbio.2006.06.015.

Faith DP. 1992. Conservation Evaluation and Phylogenetic Diversity. Biological Conservation 61:1-10.

Fitter AH. 2005. Darkness visible: reflections on underground ecology. Journal of Ecology 93:231-243 DOI 10.1111/j.0022-0477.2005.00990.x. 
392

393

394

395

396

397

398

399

400

401

402

403

404

405

406

407

408

409

410

411

412

413

414

Gianinazzi S, Gollotte A, Binet MN, van Tuinen D, Redecker D, Wipf D. 2010. Agroecology: the key role of arbuscular mycorrhizas in ecosystem services. Mycorrhiza 20:519-530 DOI 10.1007/s00572-010-0333-3.

Hacker RB, Toole ID, Melville GJ. 2011. Effects of nitrogen and phosphorus on vegetation dynamics of a degraded native grassland in semi-arid south-eastern Australia. The Rangeland Journal 33:87-97 DOI 10.1071/RJ10030.

Harpole WS, Ngai JT, Cleland EE, Seabloom EW, Borer ET, Bracken MES, Elser JJ, Gruner DS, Hillebrand H, Shurin JB, Smith JE. 2011. Nutrient co-limitation of primary producer communities. Ecology Letters 14:852-862 DOI 10.1111/j.14610248.2011.01651.x.

Hausmann NT, Hawkes CV. 2009. Plant neighborhood control of arbuscular mycorrhizal community composition. New Phytologist 183:1188-1200 DOI 10.1111/j.14698137.2009.02882.x.

Hautier Y, Niklaus PA, Hector A. 2009. Competition for light causes plant biodiversity loss after eutrophication. Science 324:636-638 DOI 10.1126/science.1169640. Heil GW, Bruggink M. 1987. Competition for nutrients between Calluna vulgaris (L.) Hull and Molina caerulea (L.) Moench. Oecologia 73:105-108.

Helgason T, Merryweather JW, Young JPW, Fitter AH. 2007. Specificity and resilience in the arbuscular mycorrhizal fungi of a natural woodland community. Journal of Ecology 95:623-630 DOI 10.1111/j.1365-2745.2007.01239.x.

Herron GJ, Sheley RL, Maxwell BD, Jacobsen JS. 2001. Influence of nutrient availability on the interaction between spotted knapweed and bluebunch wheatgrass. Restoration Ecology 9:326-331 DOI 10.1046/j.1526-100x.2001.009003326.x. 
415

416

417

418

419

420

421

422

423

424

425

426

427

428

429

430

431

432

433

434

435

436

437

438

439

Hijri I, ykorova Z, Oehl F, Ineichen K, Mader P, Wiemken A, Redecker D. 2006.

Communities of arbuscular mycorrhizal fungi in arable soils are not necessarily low in diversity. Molecular Ecology 15:2277-2289 DOI 10.1111/j.1365-294X.2006.02921.x

.Hobbs RJ, Gulmon SL, Hobbs VJ, Mooney HA. 1988. Effects of fertilizer addition and subsequent gopher disturbance on a serpentine annual grassland community. Oecologia 75:291-295.

Huenneke LF, Hamburg SP, Koide R, Mooney HA, Vitousek PM. 1990. Effects of soil resources on plant invasion and community structure in Californian serpentine grassland. Ecology 71:478-491 DOI 10.2307/1940302.

Johnson NC. 1993. Can fertilization of soil select less mutualistic mycorrhizae? Ecological Applications 3:749-757 DOI 10.2307/1942106.

Johnson D, Vandenkoornhuyse PJ, Leake JR, Gilbert L, Booth RE, Grime JP, Young JPW, Read DJ. 2004. Plant communities affect arbuscular mycorrhizal fungal diversity and community composition in grassland microcosms. New Phytologist 161:503-515 DOI 10.1046/j.1469-8137.2003.00938.x.

Johnson NC. 2010. Resource stoichiometry elucidates the structure and function of arbuscular mycorrhizas across scales. New Phytologist 185:631-647 DOI 10.1111/j.14698137.2009.03110.x.

Klabi R, Bell TH, Hamel C, Iwaasa A, Schellenberg M, Raies A, St-Arnaud M. 2015. Plant assemblage composition and soil P concentration differentially affect communities of AM and total fungi in a semi-arid grassland. FEMS Microbiology Ecology 91:1-13 DOI 10.1093/femsec/fiu015.

Landis FC, Gargas A, Givnish TJ. 2004. Relationships among arbuscular mycorrhizal fungi, vascular plants and environmental conditions in oak savannas. New Phytologist 164:493504 DOI 10.1111/j.1469-8137.2004.01202.x. 
440

441

442

443

444

445

446

447

448

449

450

451

452

453

454

455

456

457

458

459

460

461

LeBauer DS, Treseder KK. 2008. Nitrogen limitation of net primary productivity in terrestrial ecosystems is globally distributed. Ecology 89:371-379 DOI 10.1890/06-2057.1.

Lekberg Y, Gibbons SM, Rosendahl S, Ramsey PW. 2013. Severe plant invasions can increase mycorrhizal fungal abundance and diversity. The ISME Journal 7:1424-1433 DOI 10.1038/ismej.2013.41.

Li JH, Yang YJ, Li BW, Li WJ, Wang G, Knops JMH. 2014. Effects of nitrogen and phosphorus fertilization on soil carbon fractions in alpine meadows on the QinghaiTibetan Plateau. Plos One 9:e103266 DOI 10.1371/journal.pone.0103266.

Lin XG, Feng YZ, Zhang HY, Chen RR, Wang JH, Zhang JB, Chu HY. 2012. Long-term balanced fertilization decreases arbuscular mycorrhizal fungal diversity in an arable soil in North China revealed by 454 pyrosequencing. Environmental Science and Technology 46:5764-5771 DOI 10.1021/es3001695.

Liu L, Gundersen P, Zhang T, Mo J. 2012a. Effects of phosphorus addition on soil microbial biomass and community composition in three forest types in tropical China. Soil Biology and Biochemistry 44:31-38 DOI 10.1016/j.soilbio.2011.08.017.

Liu Y, G. Shi L, Mao G, Cheng S, Jiang X, Ma L, An G, Du N, Collins Johnson N, Feng H. 2012b. Direct and indirect influences of $8 \mathrm{yr}$ of nitrogen and phosphorus fertilization on Glomeromycota in an alpine meadow ecosystem. New Phytologist 194:523-535 DOI 10.1111/j.1469-8137.2012.04050.x.

Lovell RD, Jarvis SC, Bardgett RD. 1995. Soil Microbial Biomass and Activity in Long-Term Grassland: Effects of Management Changes. Soil Biology and Biochemistry 27: 969-975 DOI 10.1016/0038-0717(94)00241-R. 
Lü XT, Reed S, Yu Q, He NP, Wang ZW, Han XG. 2013. Convergent responses of nitrogen and phosphorus resorption to nitrogen inputs in a semiarid grassland. Global Change Biology 19:2775-2784 DOI 10.1111/gcb.12235.

Lumini E, Orgiazzi A, Borriello R, Bonfante P, Bianciotto V. 2010. Disclosing arbuscular mycorrhizal fungal biodiversity in soil through a land-use gradient using a pyrosequencing approach. Environmental Microbiology 12:165-2179 DOI 10.1111/j.1462-2920.2009.02099.x.Luo YQ, Hui DF, Zhang DQ. 2006. Elevated CO2 stimulates net accumulations of carbon and nitrogen in land ecosystems: A meta-analysis. Ecology 87:53-63 DOI 10.1890/04-1724.

Mack MC, Schuur EAG, Bret-Harte MS, Shaver GR, Chapin FS. 2004. Ecosystem carbon storage in arctic tundra reduced by long-term nutrient fertilization. Nature 431:440-443 DOI 10.1038/nature02887.

Magoc T, Salzberg SL. 2011. FLASH: fast length adjustment of short reads to improve genome assemblies. Bioinformatics 27:2957-2963 DOI 10.1093/bioinformatics/btr507.

Maherali H, Klironomos JN. 2012. Phylogenetic and Trait-Based Assembly of Arbuscular Mycorrhizal Fungal Communities. Plos One 7:e36695 DOI 10.1371/journal.pone.0036695.

Miransari M, Bahrami HA, Rejali F, Malakouti MJ. 2008. Using arbuscular mycorrhiza to alleviate the stress of soil compaction on wheat (Triticum aestivum L.) growth. Soil Biology and Biochemistry 40:1197-1206 DOI 10.1016/j.soilbio.2007.12.014.

Moora M, Öpik M, Sen R, Zobel M. 2004. Native arbuscular mycorrhizal fungal communities differentially influence the seedling performance of rare and common Pulsatilla species. Functional Ecology 18:554-562 DOI 10.1111/j.0269-8463.2004.00876.x. 
485

486

487

488

489

490

491

492

493

494

495

496

497

498

499

500

501

502

503

504

505

506

507

508

509

Oehl F, Sieverding E, Ineichen K, Ris EA, Boller T, Wiemken A. 2005. Community structure of arbuscular mycorrhizal fungi at different soil depths in extensively and intensively managed agroecosystems. New Phytologist 165:273-283 DOI 10.1111/j.14698137.2004.01235.x.

Öpik M, Moora M, Zobel M, Saks U, Wheatley R, Wright F, Daniell T. 2008. High diversity of arbuscular mycorrhizal fungi in a boreal herb-rich coniferous forest. New Phytologist 179:867-876 DOI 10.1111/j.1469-8137.2008.02515.x.

Öpik M, Metsis M, Daniell TJ, Zobel M, Moora M. 2009. Large-scale parallel 454 sequencing reveals host ecological group specificity of arbuscular mycorrhizal fungi in a boreonemoral forest. New Phytologist 184:424-437 DOI 10.1111/j.14698137.2009.02920.x.

Öpik M, Vanatoa A, Vanatoa E, Moora M, Davison J, Kalwij JM, Reier U, Zobel M. 2010. The online database MaarjAM reveals global and ecosystemic distribution patterns in arbuscular mycorrhizal fungi (Glomeromycota). New Phytologist 188:223-241 DOI 10.1111/j.1469-8137.2010.03334.x.

Ostertag R, Verville JH. 2002. Fertilization with nitrogen and phosphorus increases abundance of non-native species in Hawaiian montane forests. Plant Ecology 162:77-90 DOI 10.1023/A:1020332824836.Porras-Alfaro A, Herrera J, Natvig DO, Sinsabaugh RL. 2007. Effect of long-term nitrogen fertilization on mycorrhizal fungi associated with a dominant grass in a semiarid grassland. Plant and Soil 296:65-75 DOI 10.1007/s11104007-9290-9.

Ramirez KS, Lauber CL, Knight R, Bradford MA, Fierer N. 2010. Consistent effects of nitrogen fertilization on soil bacterial communities in contrasting systems. Ecology 91:3463-3470 DOI 10.1890/10-0426.1.

Smith SE, Read DJ. 2008. Mycorrhizal symbiosis. Cambridge, UK: Academic Press. 
510 Stahlberg S. 1980. New extraction method for estimation of plant-available P, K and Mg-trial

511

512

513

514

515

516

517

518

519

520

521

522

523

524

525

526

527

528

529

530

531

532

533

534 application in swedish cultivated soils. Acta Agriculturae Scandinavica 30:93-107 DOI $10.1080 / 00015128009435700$.

Sun RB, Zhang XX, Guo XS, Wang DZ, Chu HY. 2015. Bacterial diversity in soils subjected to long-term chemical fertilization can be more stably maintained with the addition of livestock manure than wheat straw. Soil Biology and Biochemistry 88:9-18 DOI 10.1016/j.soilbio.2015.05.007.Tilman D. 1987. Secondary succession and the pattern of plant dominance along experimental nitrogen gradients. Ecological Monographs 57:189214 DOI 10.2307/2937080.

van der Heijden MG, Boller T, Wiemken A, Sanders IR. 1998a. Different arbuscular mycorrhizal fungal species are potential determinants of plant community structure. Ecology 79:2082-2091 DOI 10.1890/0012-9658(1998)079[2082:DAMFSA]2.0.CO;2.

van der Heijden MG, Klironomos JN, Ursic M, Moutoglis P, Streitwolf-Engel R, Boller T, Wiemken A, Sanders IR. 1998b. Mycorrhizal fungal diversity determines plant biodiversity, ecosystem variability and productivity. Nature 396:69-72 DOI $10.1038 / 23932$.

Vandenkoornhuyse P, Ridgway KP, Watson IJ, Fitter AH, Young JPW. 2003. Co-existing grass species have distinctive arbuscular mycorrhizal communities. Molecular Ecology 12:3085-3095 DOI 10.1046/j.1365-294X.2003.01967.x.

Vitousek PM, Porder S, Houlton BZ, Chadwick OA. 2010. Terrestrial phosphorus limitation: mechanisms, implications, and nitrogen-phosphorus interactions. Ecological Applications 20:5-15 DOI 10.1890/08-0127.1.

Walkley A, Black IA. 1934. An examination of the Degtjareff method for determining soil organic matter, and a proposed modification of the chromic acid titration method. Soil Science 37:29-38 DOI 10.1097/00010694-193401000-00003. 
535

536

537

538

539

540

541

542

543

544

Wen L, Wen L, Dong SK, Li YY, Li XY, Shi JJ, Wang YL, Liu DM, Ma YS. 2013. Effect of degradation intensity on grassland ecosystem services in the alpine region of QinghaiTibetan Plateau, China. Plos One 8:e58432 DOI 10.1371/journal.pone.0058432.

Wu B, Hogetsu T, Isobe K, Ishii R. 2007. Community structure of arbuscular mycorrhizal fungi in a primary successional volcanic desert on the southeast slope of Mount Fuji. Mycorrhiza 17:495-506 DOI 10.1007/s00572-007-0114-9.

Xiang XJ, Gibbons SM, Yang J, Kong JJ, Sun RB, Chu HY. 2015. Arbuscular mycorrhizal fungal communities show low resistance and high resilience to wildfire disturbance. Plant and Soil 397:347-356 DOI 10.1007/s11104-015-2633-z.

Yuan H, Ge T, Wu X, Liu S, Tong C, Qin H, Wu M, Wei W, Wu J. 2012. Long-term field fertilization alters the diversity of autotrophic bacteria based on the ribulose-1,5biphosphate carboxylase/oxygenase (RubisCO) large-subunit genes in paddy soil. Applied Microbiology and Biotechnology 95:1061-1071 DOI 10.1007/s00253-011-3760y.

Zangaro W, Rostirola LV, de Souza PB, de Almedia Alves RD, Lescano LE, Rondina AB, Nogueira MA, Carrenho R. 2013. Root colonization and spore abundance of arbuscular mycorrhizal fungi in distinct successional stages from an Atlantic rainforest biome in southern Brazil. Mycorrhiza 23:221-233 DOI 10.1007/s00572-012-0464-9.

Zeng J, Liu X, Song L, Lin XG, Zhang HY, Shen CC, Chu HY. 2015. Nitrogen fertilization directly affects soil bacterial diversity and indirectly affects bacterial community composition. Soil Biology and Biochemistry 92:41-49 DOI: 10.1016/j.soilbio.2015.09.018.

Zhang RY, Gou X, Bai Y, Zhao J, Chen LY, Song X, Wang G. 2011. Biomass fraction of graminoids and forbs in N-limited alpine grassland N:P stoichiometry. Polish Journal of Ecology 59:105-114. 
560 Zhou X, FornaraD, Wasson EA, Wang D, Ren G, Christie P, Jia Z. 2015. Effects of 44 years 561 of chronic nitrogen fertilization on the soil nitrifying community of permanent grassland. 562 Soil Biology and Biochemistry 91:76-83 DOI 10.1016/j.soilbio.2015.08.031.

Zhu XC, Song FB, Xu HW. 2010. Arbuscular mycorrhizae improves low temperature stress in maize via alterations in host water status and photosynthesis. Plant and Soil 331:129-137 DOI 10.1007/s11104-009-0239-z. 


\section{Figure legends}

567 Fig. 1: Venn diagram showing the co-occurence of the OTUs among samples from different

568

569

570

571

572

573

574

575

576

577

578

579

580

581

582

583

584

585

586

587

treatments at the QTP station. Numbers in parentheses indicate total OTUs in each treatment group, and numbers inside the Venn diagram indicate unique and shared OTUs. OTU: operational taxonomic unit.

Fig. 2: Soil AMF alpha-diversity (OTU richness and phylogenetic diversity) calculated at a rarefaction depth of 1,000 randomly selected sequences per sample in soils across different treatments. Different letters represent significant differences from Tukey's HSD comparisons $(P$ $<0.05)$. Error bars denote standard deviation. OTU: operational taxonomic unit.

Fig. 3: Relative abundances of dominant $A M F$ families across control and fertilization (N, $P$ and NP) treatments at the QTP station. Error bars denote standard deviation calculated from 5 samples; different letters represent significant differences from Tukey's HSD comparisons $(P<$ $0.05)$.

Fig. 4: Significant responses of AMF Operational Taxonomic Units (OTUs) after N, P and NP fertilization relative to control plots. Significance was determined using a $95 \%$ confidence interval (CI), according to response ratio method.

Fig. 5: NMDS plot of AMF community composition across control and fertilization (N, P and NP) treatments at the QTP station. 
1

Venn diagram showing the co-occurence of the OTUs among samples from different treatments at the QTP station.

Fig. 1: Venn diagram showing the co-occurence of the OTUs among samples from different treatments at the QTP station. Numbers in parentheses indicate total OTUs in each treatment group, and numbers inside the Venn diagram indicate unique and shared OTUs. OTU: operational taxonomic unit.

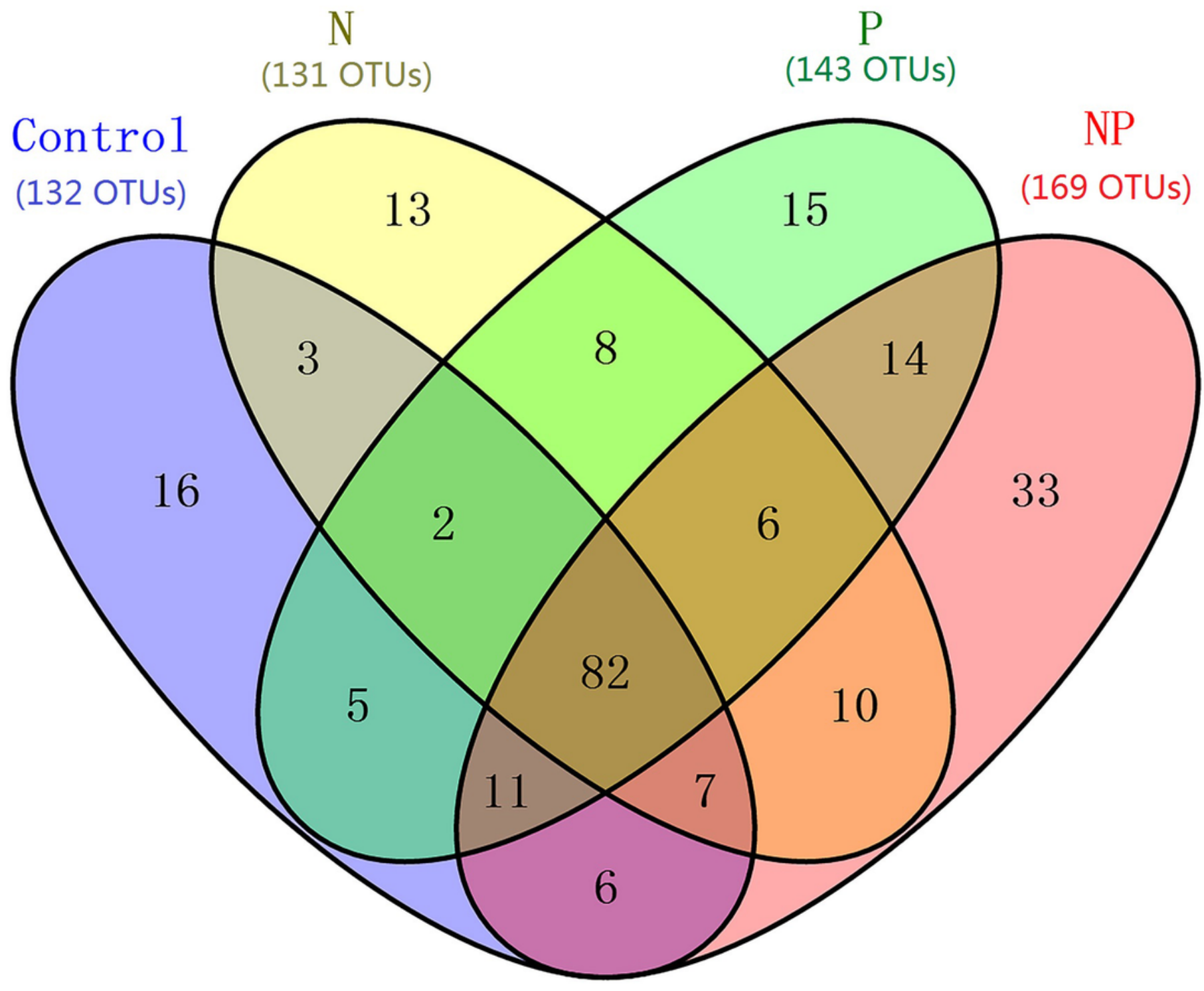


2

Soil AMF alpha-diversity

Fig. 2: Soil AMF alpha-diversity (OTU richness and phylogenetic diversity) calculated at a rarefaction depth of 1,000 randomly selected sequences per sample in soils across different treatments. Different letters represent significant differences from Tukey's HSD comparisons $(P<0.05)$. Error bars denote standard deviation. OTU: operational taxonomic unit. 


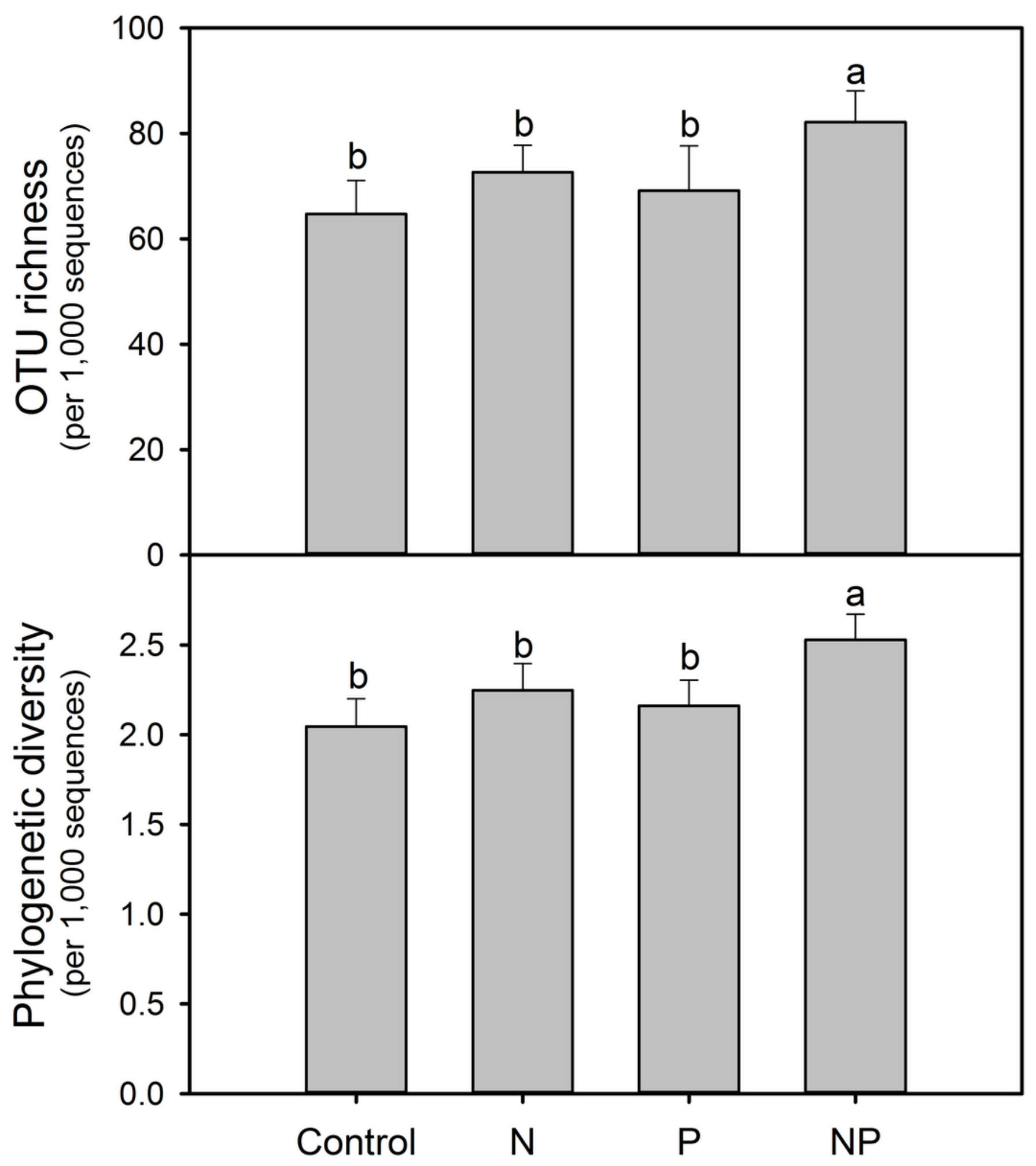


3

Soil AMF dominant families

Fig. 3: Relative abundances of dominant AMF families across control and fertilization (N, P and NP) treatments at the QTP station. Error bars denote standard deviation calculated from 5 samples; different letters represent significant differences from Tukey's HSD comparisons $(P<0.05)$. 


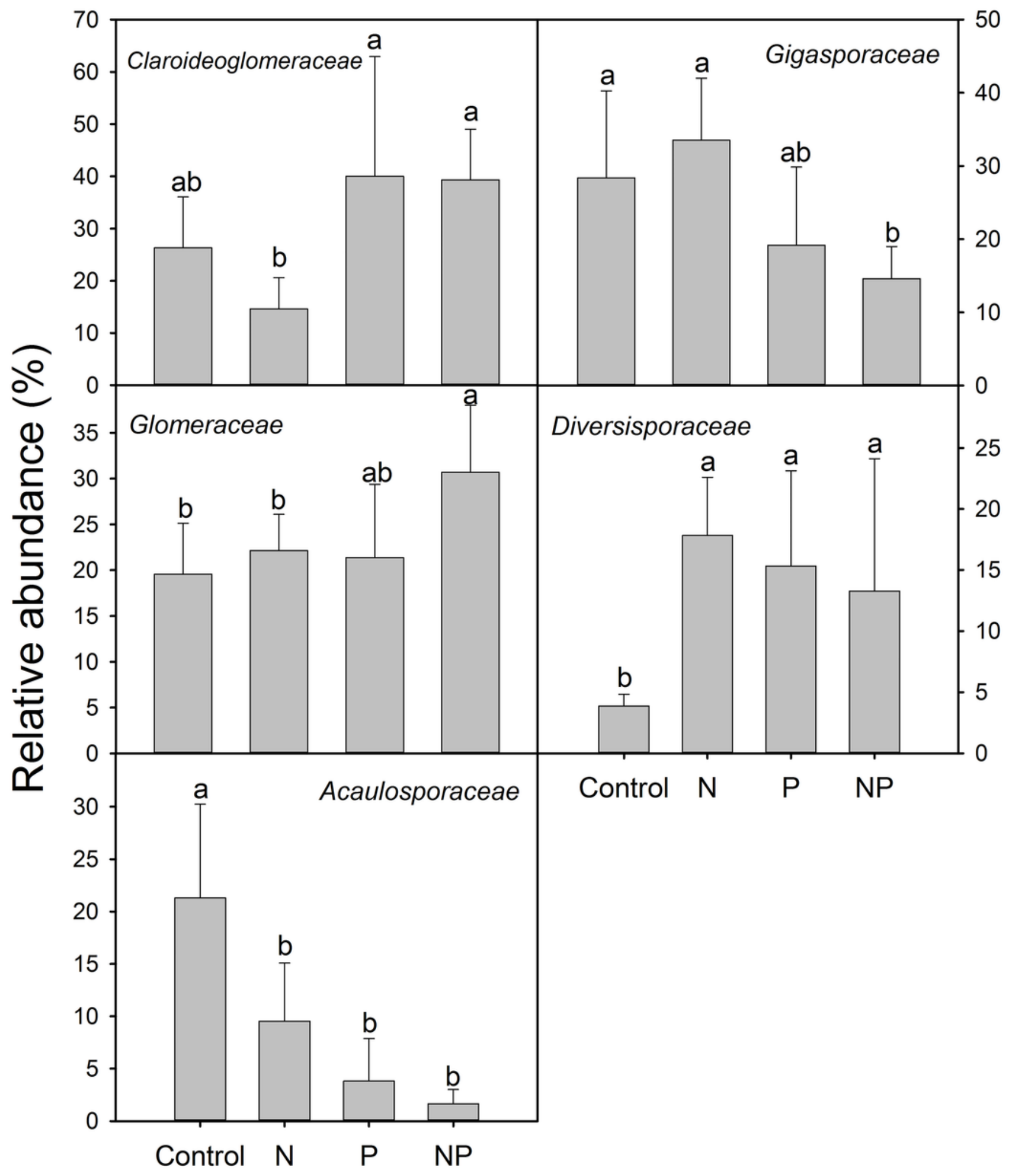


4

Response ratio for AMF OTUs

Fig. 4: Significant responses of AMF Operational Taxonomic Units (OTUs) after N, P and NP fertilization relative to control plots. Significance was determined using a $95 \%$ confidence interval $(\mathrm{Cl})$, according to response ratio method. 


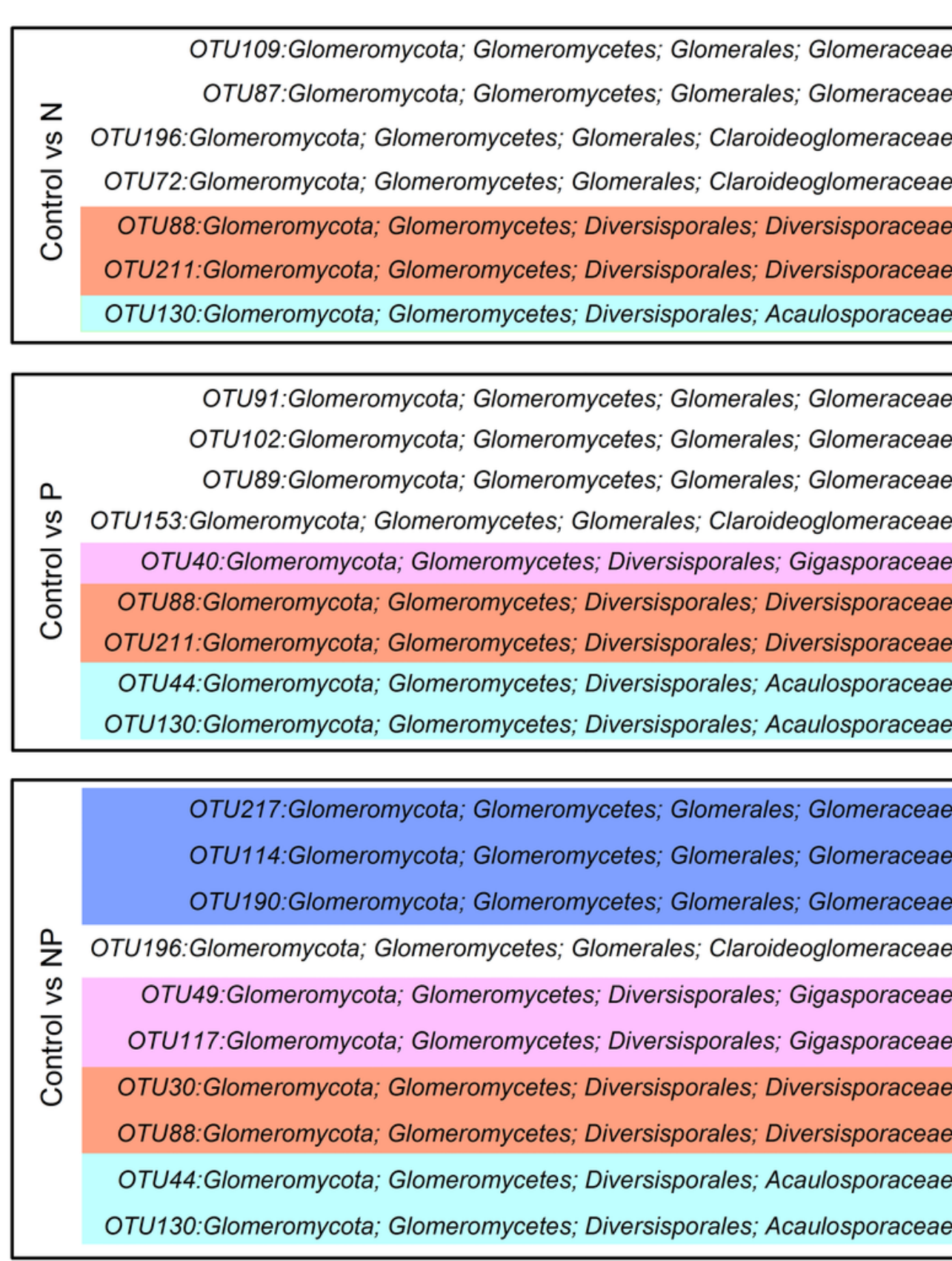

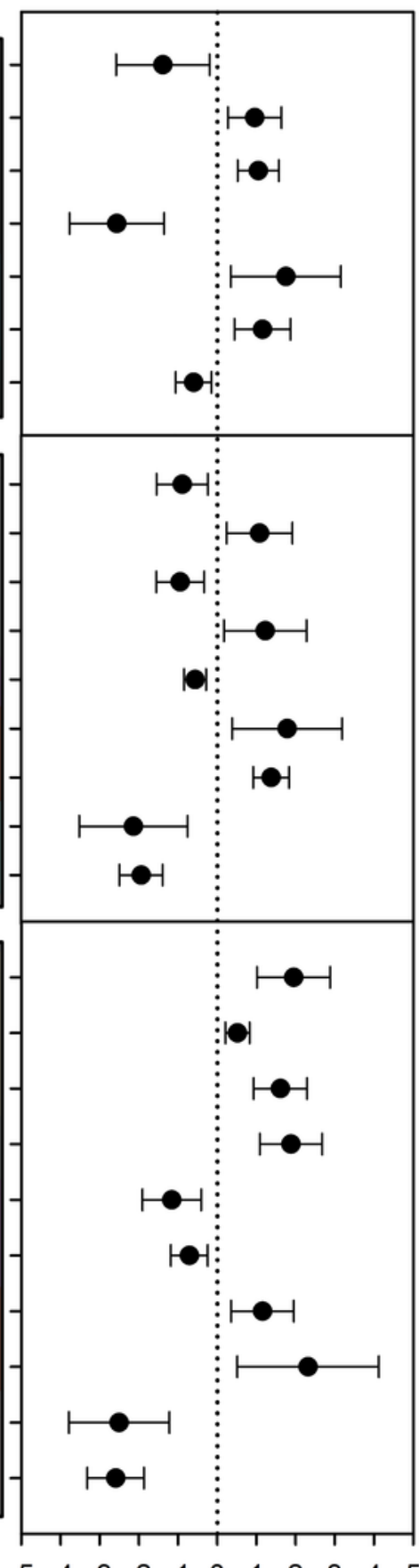

$\begin{array}{lllllllllll}-5 & -4 & -3 & -2 & -1 & 0 & 1 & 2 & 3 & 4 & 5\end{array}$

Response ratio at $95 \% \mathrm{Cl}$ 
5

NMDS plot of AMF community composition

Fig. 5: NMDS plot of AMF community composition across control and fertilization (N, P and NP) treatments at the QTP station.

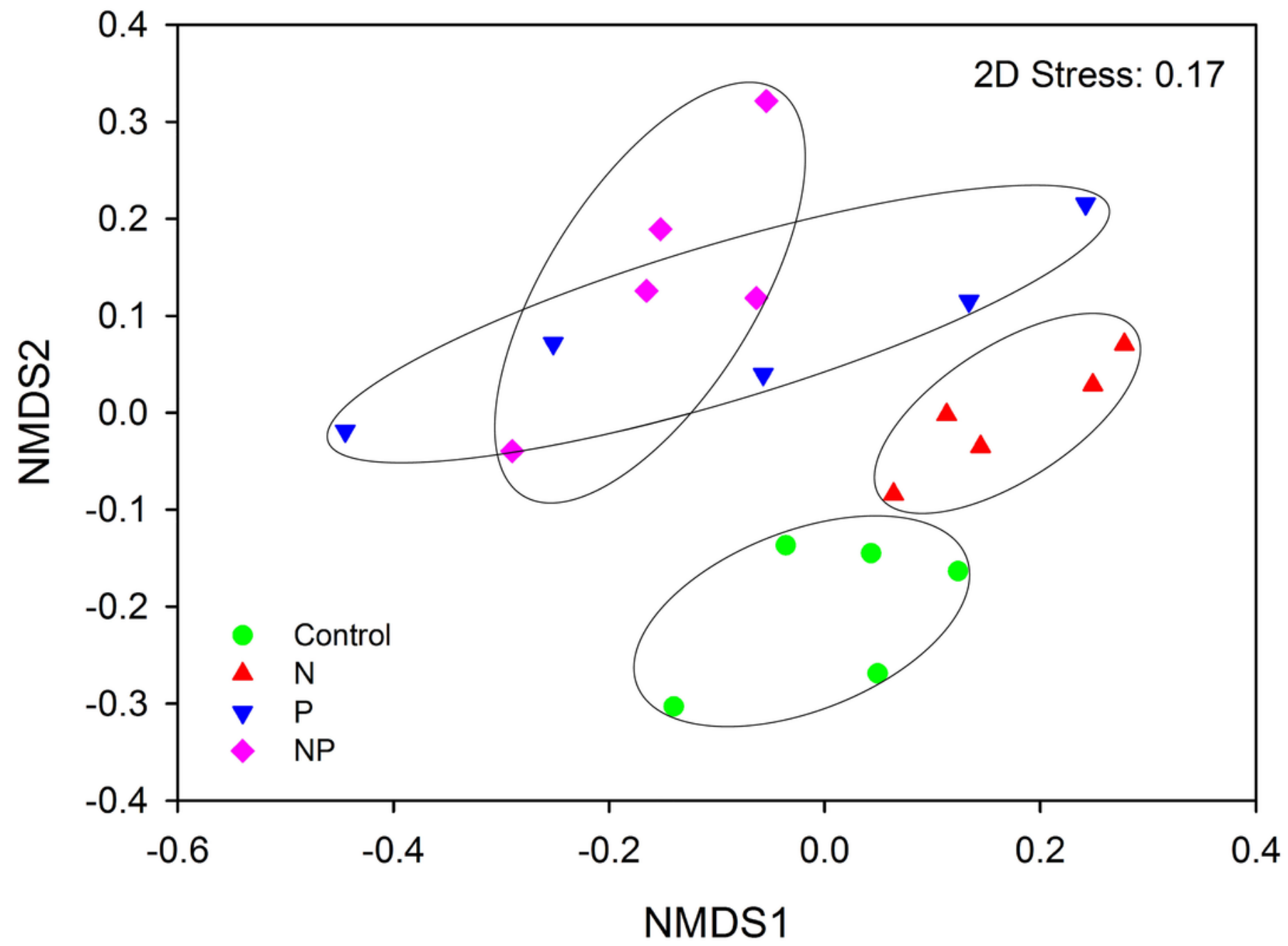

